\title{
Effect of nitric oxide on the expression of insulin-like growth factors and insulin-like growth factor binding proteins throughout the lifespan of the human corpus luteum
}

\author{
G. Iñiguez ${ }^{1}$, A. Villavicencio ${ }^{1 *}$, F. Gabler ${ }^{2}$, \\ A. Palomino ${ }^{1}$ and M. Vega ${ }^{1+}$ \\ ${ }^{1}$ Institute of Maternal and Child Research and ${ }^{2}$ Pathology Department, San Borja-Arriarán \\ Clinical Hospital, School of Medicine, University of Chile, Santiago, Chile
}

The presence of insulin-like growth factors (IGF), IGF binding proteins (IGFBP) and IGF receptor type 1 (IGF-IR) in the human corpus luteum was investigated by examining the expression and production of related proteins throughout the lifespan of the corpus luteum and the action of nitric oxide upon their production. The expression of proteins in corpora lutea from the early, midand late luteal phases was assessed by immunohistochemistry, evaluated by a semi-quantitative analysis and the functional study was performed in corpus luteum explants incubated with nitric oxide donors. IGF-I and -II and IGFBP-1 and -3 were measured in the culture media by specific immunoassays. The results showed that IGF-I and -II, IGFBP-1 to - 6 and IGF-IR were detected in the human corpus luteum throughout the luteal phase. Moreover, the expression and production of IGF-I and IGFBP-1 increased progressively from corpora lutea from the early to late

\section{Introduction}

The corpus luteum is a transitory gland formed by distinct types of cell, including steroidogenic cells, endothelial cells, fibroblasts and leucocytes, which interact via their secreted products. Some of these products act as intraovarian regulators of the menstrual cycle (Remohi et al., 1996; Castro et al., 1998), for example the insulin-like growth factors, IGF-I and -II (Remohi et al., 1996). The biological actions of IGF-I and -II, which include proliferation and cellular differentiation, are regulated by six binding proteins named IGFBP- 1 to -6 (Feld and Hirschberg et al., 1996).

The transcripts of IGF-I and its receptor (IGF-IR) have been detected in the ovary of several species, including rats (Parmer et al., 1991), cows (Einspanier et al., 1990; Sauerwein et al., 1992), pigs (Perks et al., 1995) and women

*PLACIRH Fellow

${ }^{+}$Correspondence: M. Vega, PO Box 226-3, IDIMI, University of Chile, Santiago, Chile

Email:mvega@machi.med.uchile.cl luteal phases $(P<0.05)$, whereas the expression and production of IGFBP-2, -4 and -5 were significantly higher in corpora lutea from the mid-luteal phase $(P<0.05)$. No differences were observed in the expression of IGF-II, IGFBP-3 and -6 and IGF-IR throughout the lifespan of the corpus luteum. However, functional studies showed that nitric oxide donors elicited a stimulatory action on production of IGF-I in corpora lutea from the early luteal phase $(80 \%)$ and on production of IGFBP-1 in corpora lutea from the late luteal phase $(50 \%)(P<0.05)$, whereas production of IGF-II and IGFBP-3 was not affected by nitric oxide. In conclusion, the components of the IGF-IGFBP system are expressed in the human corpus luteum throughout its lifespan. Nitric oxide regulates IGF-I and IGFBP-1 production, indicating that the growth factors may serve, at least in part, as mediators of the action of nitric oxide in the human corpus luteum.
(Johnson et al., 1996). Functional studies have shown that IGF-I stimulates progesterone production by the rat corpus luteum (Parmer et al., 1991), which increases when the cells are stimulated simultaneously with IGF-I and hCG (Talavera and Menon, 1991). Similar results have been reported in human luteal cells, in which IGF-I enhances both basal and hCG-stimulated progesterone production (Devoto et al., 1995). In addition, IGF-I induces an increase in oestradiol secretion by human luteinized granulosa cells and by luteal cells in culture (Erickson et al., 1989; Johnson et al., 1996). These results indicate that IGF-I has a role in the regulation of the steroidogenic function of the human corpus luteum. Furthermore, IGF-I has an important antiapoptotic effect in various tissues (Janiga et al., 2000; Morales et al., 2000; Remacle et al., 2000) and regulates the relative concentrations of several members of the $\mathrm{Bcl}-2$ family (Dews et al., 2000).

The production of IGFBP-2 to -5 has been detected in the corpora lutea of pigs (Gadsby et al., 1996) and cows (Kirby et al., 1996), and in the normal ovaries of women, where IGFBP-1 to -5 have been detected in dominant follicles (El-Roeiy et al., 1994). As yet, few studies have 
been performed regarding IGFBPs in the human corpus luteum. However, the production and secretion of IGFBP-1 in human luteinized granulosa cells has been reported (Angervo et al., 1991; Holst et al.,1997). In addition, IGFBP3 mRNA is expressed in the endothelial cells of the human corpus luteum (Fraser et al., 2000).

Nitric oxide (NO) is produced in most tissues and may regulate different physiological functions, some of which are associated with reproductive processes (Norman and Cameron, 1996). Endothelial and inducible NO synthases are expressed in the human corpus luteum throughout its lifespan (Vega et al., 1998). As has been described in other tissues (Dimmeler and Zeiher, 1997), NO has an antisteroidogenic action (Johnson et al., 1999) and induces apoptosis in the human corpus luteum (Vega et al., 2000). The aims of the present study were to investigate the presence and production of IGFs and IGFBPs in the human corpus luteum throughout the luteal phase and to determine whether NO induces a modification in the concentration of these proteins in luteal tissue explants.

\section{Materials and Methods}

\section{Materials}

All chemicals were purchased from Sigma Chemical Co. (St Louis, MO) and culture media were obtained from GibcoBRL, Life Technologies (Grand Island, NY). Human recombinant IGF-I and IGF-II were obtained from Bachem (Torrance, CA). Polyclonal anti-IGF-I (NIH-AFP 4892898) was obtained from NHPP, NIDDK and Dr Parlow (National Hormone and Peptide Program, Torrance, CA). Polyclonal anti-IGF-II, anti-IGFBP-1, anti-IGFBP-2 and anti-IGFBP-3 were obtained from GroPep (North Adelaide, SA), monoclonal anti-IGFBP-4, anti-IGFBP-5 and anti-IGFBP-6 were obtained from Austral Biologicals (San Ramon, CA), and monoclonal anti-IGF-IR (Ab-1) was obtained from Oncogene Research Products (Cambridge, MA). IGF-I and IGF-Il were determined as described by García et al. (1996). In brief, recombinant IGFs were iodinated using the Chloramine $\mathrm{T}$ method (vanObberghen-Schilling and Pouyssegur, 1983). Radiolabelled peptides were separated from the free iodine by gel filtration on Sephadex G-50 columns $(1 \mathrm{~cm} \times 50 \mathrm{~cm})$. The specific activity was approximately $300 \mathrm{mCi} \mathrm{mg}^{-1}$ for IGF-I and $190 \mathrm{mCi} \mathrm{mg}^{-1}$ for IGF-II, and the corresponding standard curves were established using the same recombinant peptides. The concentrations of IGFBP-1 and IGFBP-3 were measured by immunoradiometric assay, and progesterone and oestradiol were measured by radioimmunoassay from Diagnostic System Laboratories (Webster, TX).

\section{Subjects}

Corpora lutea were obtained from 12 women aged 33-45 with normal menstrual histories who were undergoing minilaparotomy for tubal sterilization at the San Borja-Arriarán Clinical Hospital, University of Chile,
National Health Service (Santiago, Chile). The study was approved by the Institutional Ethics Committee and an informed written consent was obtained from all patients before surgery. The day of the menstrual cycle of each woman on which the tissue had been obtained was confirmed by ultrasonographic and histological analysis of endometria, according to the criteria of Noyes et al. (1950). After removal of the corpus luteum, the tissue was placed in a sterile PBS and transported immediately to the laboratory at room temperature. The tissues were then cut into slices, the masses of which ranged from 15 to $60 \mathrm{mg}$ (wet mass). Two or three slices (explants) from each corpus luteum were incubated separately for each experimental condition (basal or L-arginine treatment). One piece of each corpus luteum was placed in $4 \%(\mathrm{v} / \mathrm{v})$ formalin-PBS $\left(0.1 \mathrm{~mol} \mathrm{I}^{-1}, \mathrm{pH} 7.2-7.4\right)$ for histological evaluation and immunohistochemistry, and the corpora lutea were classified as from the early (days 1-4 after ovulation), mid- (days 5-9 after ovulation) and late (days 10-14 after ovulation) luteal phases.

\section{Incubation procedures}

For experiments designed to test the influence of $\mathrm{NO}$ on production of oestradiol, progesterone, IGF-I and -II, and IGFBP-1 and -3, tissue explants were incubated as described by Vega et al. (2000). In brief, corpus luteum slices were placed into four-well plates with Hank's (L-Arginine-free) medium, supplemented with $0.1 \mathrm{mg}$ glutamine $\mathrm{ml}^{-1}, 1 \mathrm{mg} \mathrm{BSA} \mathrm{ml}-1,26 \mathrm{mmol} \mathrm{NaHCO}_{3} \mathrm{I}^{-1}$, $25 \mathrm{mmol}^{-}$epes $\mathrm{I}^{-1}$ and antibiotics (60 iu penicillin $\mathrm{ml}^{-1}$ and $5 \mathrm{mg}$ streptomycin $\left.\mathrm{ml}^{-1}\right)(\mathrm{pH} 7.4)$, to give a final volume of $0.5 \mathrm{ml}$. Basal and treated conditions were carried out in duplicates or triplicates. NO synthase substrate, $1.0 \mathrm{mmol}$ L-Arginine $\mathrm{I}^{-1}$ was then added to some plates. Incubations were terminated at $4 \mathrm{~h}$ and the media were stored at $-70^{\circ} \mathrm{C}$ until assayed for the different compounds. The sensitivity of the immunoassays was: 0.018 pmol oestradiol $\mathrm{ml}^{-1} ; 0.318$ pmol progesterone $\mathrm{ml}^{-1} ; 0.129$ pmol IGF-I ml-1; $1.298 \mathrm{pmol}$ IGF-II ml-1; 0.0036 pmol IGFBP-1 $\mathrm{ml}^{-1}$ and 0.017 pmol IGFBP-3 ml-1. The intra- and interassay coefficients of variation were, respectively: oestradiol: 4.1 and $6.7 \%$; progesterone: 3.8 and 5.5\%; IGF-I: 8.6 and 10.2\%; IGF-II: 8.2 and $11.8 \%$; IGFBP-1: 3.5 and $4.2 \%$; and IGFBP-3: 1.1 and $1.8 \%$.

\section{Immunohistochemical detection of IGFs, IGFBPs and IGF-IR}

The expression of IGF-I and -II, IGFBP-1 to -6 and IGF-IR was examined in histological paraffin wax sections (4-6 $\mu \mathrm{m})$ of human corpora lutea of different ages. The antibodies and dilutions used are shown (Table 1). The second antibody was a biotinylated anti-mouse-antirabbit-anti-goat mixture immunoglobulin. The reaction was evaluated by streptavidin-biotin peroxidase conjugate using diaminobenzidine as the chromogen and cell nuclei were stained with haematoxylin. The slides were analysed in a Nikon optical microscope (Nikon Inc., Melville, NY). 
Table 1. Antibodies and dilutions used in the immunohistological study

\begin{tabular}{lll}
\hline & Antibody & Dilution \\
\hline IGF-I & Polyclonal & $1: 2000$ \\
IGF-II & Polyclonal & $1: 250$ \\
IGFBP-1 & Polyclonal & $10 \mu \mathrm{ml}^{-1}$ \\
IGFBP-2 & Polyclonal & $1: 250$ \\
IGFBP-3 & Polyclonal & $10 \mu \mathrm{ml}^{-1}$ \\
IGFBP-4 & Monoclonal & $1: 150$ \\
IGFBP-5 & Monoclonal & $1: 150$ \\
IGFBP-6 & Monoclonal & $1: 150$ \\
IGF-IR & Monoclonal & $1: 300$ \\
\hline
\end{tabular}

IGF: insulin-like growth factor; IGFBP: insulin-like growth factor binding protein.

The immunochemical evaluation for each protein was performed by a semi-quantitative analysis described by Lessey et al. (1992) named HScore (HS), which corresponds to: $[P](i+1) / 100$, where $[P]$ is the percentage of positively stained cells and $i$ is the intensity of the staining on a scale of 1-3 (1: low intensity; 2: mid-intensity; and 3: high intensity). Each protein was evaluated by three independent observers and the positive staining was assessed in at least 500 cells.

\section{Statistical analysis}

Data are expressed as means \pm SEM. For comparison between basal concentrations and immunohistochemical analysis, an unpaired Student's $t$ test was used. A paired Student's $t$ test was used to compare basal and stimulated conditions for production of IGFs and IGFBPs. $P<0.05$ was considered statistically significant.

\section{Results}

\section{Detection of IGFS, IGFBPS and IGF-IR}

The presence of IGF-I and -II was detected in human corpora lutea throughout the luteal phase (Fig. 1a,b). The number of positively stained cells and the intensity of the immunostaining (HS) for IGF-I increased progressively in luteal tissue throughout the luteal phase (Table 2). In corpora lutea from the early luteal phase, nearly $80 \%$ of the parenchyma cells showed positive staining for IGF-I, whereas in corpora lutea from the mid- and late luteal phases, 91 and 93\%, respectively, of the cells were positively stained. The HS for IGF-I in corpora lutea from the late luteal phase was significantly different from that for corpora lutea from the early luteal phase $(P<0.05)$ (Table 2). Almost $95 \%$ of the luteal cells were positively immunostained for IGF-II, regardless of the stage of the luteal phase studied.

The positive staining for IGFBP-1 to -6 is shown (Fig. 1c-h). The immunohistochemical evaluation for IGFBP-1 showed that $70 \%$ of luteal cells were positively stained (Fig. 1c), in addition to some endothelial cells, although smooth muscle cells were negative for IGFBP-1. The percentage of positively stained cells increased in corpora lutea from the mid- and late luteal phases, but this increase was not significant, whereas the HS value increased gradually in corpora lutea from the early to the mid- and late luteal phases (HS early versus corpora lutea from the late luteal phase: $P<0.05$; Table 2). Ninety per cent of cells were positively stained for IGFBP-2 during the three stages of the luteal phase, although the HS value for IGFBP-2 increased significantly in corpora lutea from the early to the mid-luteal phases $(P<0.05$; Table 2$)$. In contrast, the HS value for IGFBP-3 and the positive immunostaining (almost $100 \%$ ) did not show modifications throughout the luteal phase. Although a similar percentage of cells (95\%) stained positively for IGFBP-4 and IGFBP-5 throughout the luteal phase, the HS value for both binding proteins was significantly higher in corpora lutea from the mid- than from the early luteal phase $(P<0.05$; Table 2$)$. The immunohistochemical study for IGFBP-6 showed a non-significant increase in positively stained cells in corpora lutea from the early to the mid- and late luteal phases (from 77 to 95\%) and a similar HS value for this binding protein was observed throughout the luteal phase.

No changes were observed in the number of positively stained cells or in the HS value for IGF-IR throughout the luteal phase (Fig. 1i, Table 2). However, the distribution of staining differed with age of corpora lutea. In corpora lutea from the early and late luteal phases, the positive staining for the receptor was predominantly near the cell membrane, whereas in corpora lutea from the mid-luteal phase, staining was distributed homogeneously in the cytoplasm and plasma membrane.

\section{Basal production of oestradiol, progesterone, IGF-I, IGF- II, IGFBP-1 and IGFBP-3}

Slices of human corpora lutea of different ages were incubated for $4 \mathrm{~h}$ to assess the production of oestradiol and progesterone. Oestradiol production increased significantly in corpora lutea from the mid- and late luteal phases (2.6and 1.9 -fold, respectively, $P<0.05$ ) compared with basal production by corpora lutea from the early luteal phase (Table 3). Similarly, progesterone production increased in corpora lutea from mid- (2.9-fold) and late (2.0-fold) phases $(P<0.05)$ compared with basal production by corpora lutea from the early luteal phase.

Production of IGF-I increased significantly $(P<0.05)$ with age of corpus luteum by 2.5 -fold and 5.9 -fold in corpora lutea from the mid- and late luteal phases, respectively, compared with basal production by corpora lutea from the early luteal phase (Table 3). No significant change in IGF-II production was observed in corpora lutea of different ages, although IGF-II production was significantly lower in corpora lutea from the mid- and late luteal phases than IGF-I basal production $(P<0.05)$.

Similar to that of IGF-I, the production of IGFBP-1 increased progressively throughout the luteal phase (Table 3). Basal production of IGFBP-1 was enhanced significantly 

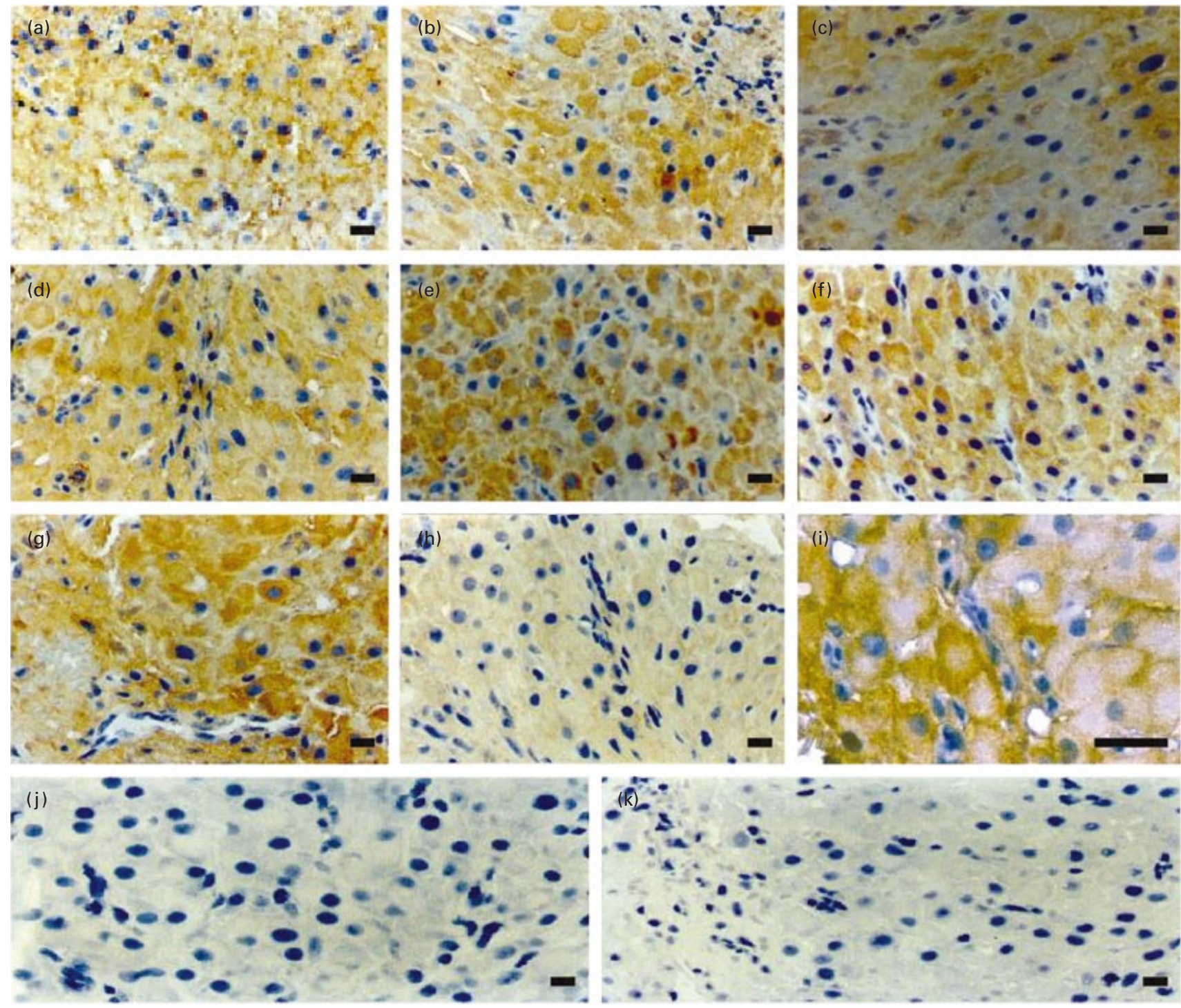

Fig. 1. Immunohistochemical detection of insulin-like growth factors (IGFs), IGF binding proteins (IGFBPs) and IGF-I receptor (IGF-IR) in paraffin wax sections of human corpus luteum from the mid-luteal phase. Intense positive staining of the cytoplasm was observed for (a) IGF-I, (b) IGF-II, (c) IGFBP-1, (d) IGFBP-2 and (e) IGFBP-3 when polyclonal antibodies against the respective proteins were used, and for (f) IGFBP-4, (g) IGFBP-5 and (i) IGF-IR when monoclonal antibodies were used. Weaker immunostaining for (h) IGFBP-6 was observed in luteal parenchyma. (j,k) Negative controls (non-immune rabbit serum and non-immune mouse serum, respectively). Scale bars represent $30 \mu \mathrm{m}$.

$(P<0.05)$ in corpora lutea from the mid- $(1.5$-fold $)$ and late (5.5-fold) luteal phases compared with basal production by corpora lutea from the early luteal phase. Basal production of IGFBP-3 was unchanged throughout the luteal phase, although its production was significantly higher than that of IGFBP-1 at all stages of the luteal phase $(P<0.05)$ (Table 3$)$.

\section{Effect of nitric oxide on production of oestradiol, progesterone, IGF-I, IGF-II, IGFBP-1 and IGFBP-3}

Explants of human corpus luteum of different ages were incubated in the presence or absence of NO synthase substrate, L-Arginine. The addition of L-Arginine had an inhibitory effect on oestradiol production in corpora lutea from the mid- $(70 \% ; P<0.05)$ and late luteal phases $(60 \%$; $P<0.05)$ compared with the corresponding basal values (Fig. 2a). The same effect was observed for progesterone production, for which there was a 60 and a $62 \%$ decrease in corpora lutea from the mid- and late luteal phase, respectively $(P<0.05)$ (Fig. 2b). No effect of the presence of L-Arginine was detected on the production of oestradiol or progesterone in corpora lutea from the early luteal phase. Similar results were obtained in corpus luteum explants incubated with sodium nitroprusside, an NO-generating 
Table 2. Immunohistochemical detection of insulin-like growth factors (IGF), IGF binding proteins (IGFBP) and IGF-I receptors (IGF-IR) in human corpora lutea from the early, mid- and late luteal phases

\begin{tabular}{lccc}
\hline & \multicolumn{3}{c}{ HScore } \\
\cline { 2 - 4 } & Early corpus luteum & Mid-corpus luteum & Late corpus luteum \\
\hline IGF-I & $1.8 \pm 0.07$ & $2.4 \pm 0.25$ & $3.0 \pm 0.29^{*}$ \\
IGF-II & $2.5 \pm 0.20$ & $3.0 \pm 0.20$ & $3.1 \pm 0.26$ \\
IGFBP-1 & $1.7 \pm 0.27$ & $2.6 \pm 0.28$ & $2.9 \pm 0.15^{*}$ \\
IGFBP-2 & $1.8 \pm 0.20$ & $2.7 \pm 0.12^{\dagger}$ & $2.7 \pm 0.15^{*}$ \\
IGFBP-3 & $3.1 \pm 0.03$ & $3.1 \pm 0.03$ & $3.1 \pm 0.06$ \\
IGFBP-4 & $2.8 \pm 0.03$ & $3.1 \pm 0.06^{+}$ & $2.8 \pm 0.17$ \\
IGFBP-5 & $2.5 \pm 0.09$ & $3.2 \pm 0.17^{\dagger}$ & $2.9 \pm 0.29$ \\
IGFBP-6 & $2.7 \pm 0.03$ & $2.6 \pm 0.09$ & $2.6 \pm 0.06$ \\
IGF-IR & $2.7 \pm 0.24$ & $2.4 \pm 0.05$ & $2.8 \pm 0.37$ \\
\hline
\end{tabular}

Tissue slices were obtained from human corpora lutea at different stages of the luteal phase and immunostained with different antibodies for the proteins studied.

HScore corresponds to the percentage of positively stained cells $[P](i+1) / 100$, where $i$ is the intensity of the staining on a scale of 1-3 (1: low intensity; 2: mid-intensity; and 3: high intensity).

Values are expressed as HScore (mean \pm SEM); ${ }^{*} P<0.05$, early corpus luteum versus late corpus luteum; ${ }^{\dagger} P<0.05$, early corpus luteum versus mid-corpus luteum.

Table 3. Concentrations of oestradiol, progesterone, insulin-like growth factor I (IGF-I) and IGF-II, IGF binding proteins 1 (IGFBP-1) and IGFBP-3 in the incubation media of human corpora lutea of different ages

\begin{tabular}{|c|c|c|c|}
\hline & Early corpus luteum & Mid-corpus luteum & Late corpus luteum \\
\hline Oestradiol (pmol g ${ }^{-1}$ corpus luteum) & $413.9 \pm 38.8$ & $1.083 \pm 61.9^{*}$ & $770.9 \pm 72.5^{*}$ \\
\hline Progesterone (nmol g $\mathrm{g}^{-1}$ corpus luteum) & $13.4 \pm 2.6$ & $38.8 \pm 2.9^{*}$ & $27.0 \pm 1.6^{*}$ \\
\hline IGF-I (pmol g-1 corpus luteum) & $31.2 \pm 15.4$ & $108.6 \pm 11.8^{*}$ & $215.4 \pm 37.0^{*}$ \\
\hline IGF-II (pmol g-1 corpus luteum) & $50.9 \pm 4.2$ & $54.9 \pm 10.1^{\dagger}$ & $59.6 \pm 9.6^{+}$ \\
\hline IGFBP-1 (pmol g-1 corpus luteum) & $0.19 \pm 0.1$ & $0.48 \pm 0.1^{*}$ & $1.24 \pm 0.4^{*}$ \\
\hline IGFBP-3 (pmol g ${ }^{-1}$ corpus luteum) & $29.7 \pm 6.6^{\ddagger}$ & $37.8 \pm 5.2^{\ddagger}$ & $37.9 \pm 5,9^{\ddagger}$ \\
\hline
\end{tabular}

Explants from human corpora lutea of different ages (three early corpora lutea, $n=8$ slices; five mid-corpora lutea, $n=12$ slices; and four late corpora lutea, $n=10$ slices) were incubated in supplemented Hank's (L-Arg free) medium for $4 \mathrm{~h}$ and the concentration of proteins in the incubation media was determined by specific immunoassays.

Data are presented as means \pm SEM.

${ }^{*} P<0.05$ compared with early corpus luteum; ${ }^{+} P<0.05$ compared with IGF-II production at the same luteal stage;

${ }^{\ddagger} P<0.05$ compared with IGFBP-1 production.

drug (data not shown), in agreement with the results of previous studies (Johnson et al., 1999; Vega et al., 2000).

Addition of L-Arginine had a stimulatory effect on IGF-I production in corpora lutea from the early luteal phase $(80 \% ; P<0.05)$ (Fig. 3a) compared with corresponding basal values, whereas no significant modification was observed in corpora lutea from the mid- or late luteal phases. In contrast, NO did not change the production of IGF-II in vitro by the human corpus luteum (Fig. 3b). However, L-Arginine induced a $50 \%$ increase in the concentration of IGFBP-1 in the incubation media of corpora lutea from the late luteal phase explants $(P<0.05)$ (Fig. 4a). In contrast, IGFBP-3 production by human corpora lutea of different ages was not modified by L-Arginine (Fig. 4b).

\section{Discussion}

Several molecules may regulate the morphological and functional changes in the corpus luteum throughout its lifespan acting via endocrine, paracrine or autocrine mechanisms. Among these molecules, NO has been suggested as a regulator of human corpus luteum function (Vega et al., 1998, 2000; Johnson et al., 1999). The NO-NO synthase system is expressed throughout the lifespan of the human corpus luteum eliciting an anti-steroidogenic effect 


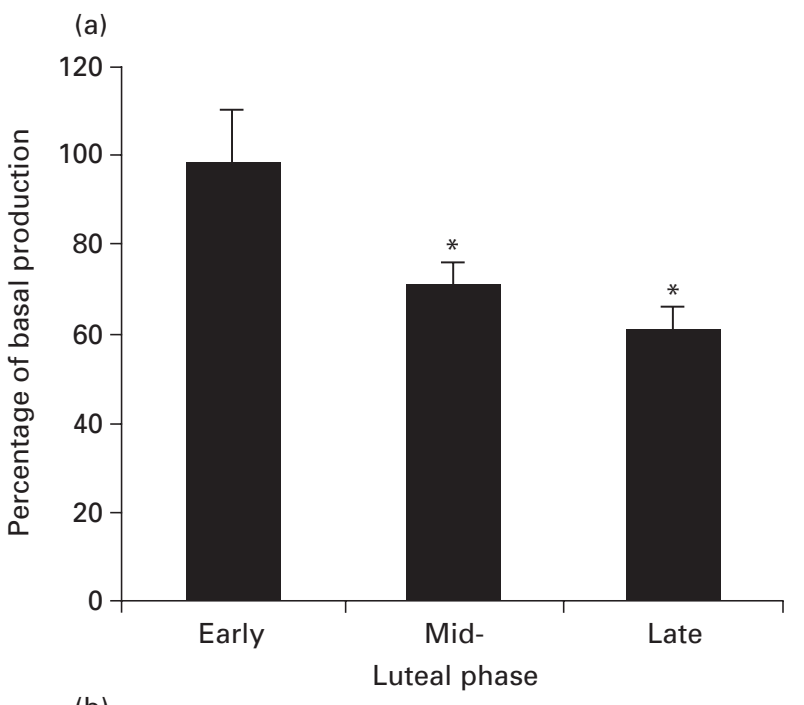

(b)

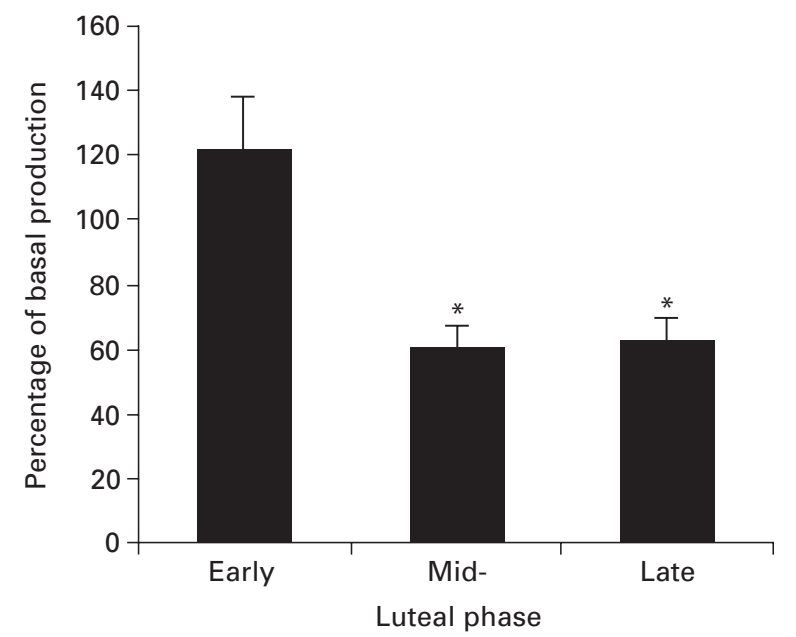

Fig. 2. Effect of nitric oxide on (a) oestradiol and (b) progesterone production by human corpus luteum during the luteal phase. Tissue explants (three corpora lutea from the early luteal phase, $n=8$ slices; five corpora lutea from the mid-luteal phase, $n=12$ slices; and four corpora lutea from the late luteal phase, $n=10$ slices) were treated with L-Arginine $\left(1 \mathrm{mmol} \mathrm{I}^{-1}\right)$ for $4 \mathrm{~h}$. Results are expressed as percentages \pm SEM of basal values (Table 3 ). ${ }^{*} P<0.05$ versus corresponding basal value.

in vitro, mainly upon oestradiol production. When $\mathrm{NO}$ synthase activity was inhibited by $\mathrm{NG}^{\mathrm{G}}$-monomethyl-Larginine L-NMMA (a competitive inhibitor of NO synthase), steroid production was enhanced, indicating an inhibitory effect of endogenous $\mathrm{NO}$ on luteal steroidogenesis. Furthermore, when dispersed luteal cells were coincubated with L-Arginine and L-NMMA, no differences in steroid production were observed (Vega et al., 1998, 2000; Johnson et al., 1999). However, IGFs and IGFBPs have been considered to elicit a regulatory role in the function of the corpus luteum (Parmer et al., 1991; Davis et al., 1996; Niswender et al., 2000). In this regard, the present
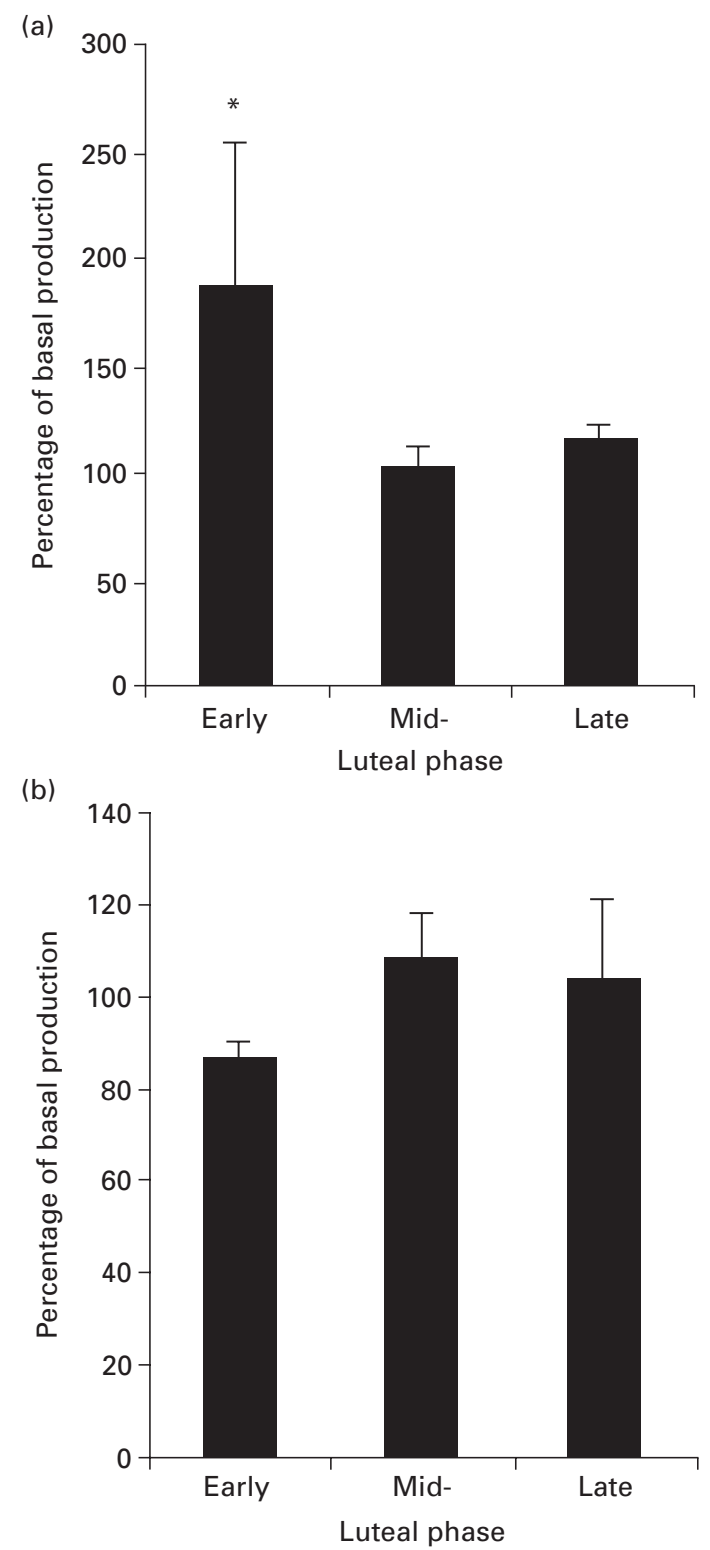

Fig. 3. Effect of nitric oxide on (a) insulin-like growth factor I (IGF-I) and (b) IGF-II production by human corpus luteum throughout the luteal phase. Tissue explants (three corpora lutea from the early luteal phase, $n=8$ slices; five corpora lutea from the mid-luteal phase, $n=12$ slices; and four corpora lutea from the late luteal phase, $n=10$ slices) were treated with L-Arginine $\left(1 \mathrm{mmol} \mathrm{I}^{-1}\right)$ for $4 \mathrm{~h}$. Results are expressed as percentages \pm SEM of basal values (Table 3$) .{ }^{*} P<0.05$ versus corresponding basal value.

investigation showed that the expression of several proteins of the IGF-IGFBP system changes during the lifespan of the human corpus luteum. Immunohistochemistry showed that maximum expression of IGFBP-2, -4 and -5 , and the detection of IGF-IR in the cell cytoplasm, occurred in midstage corpora lutea. The biological relevance of the increase in these binding proteins and the immunolocalization of the 

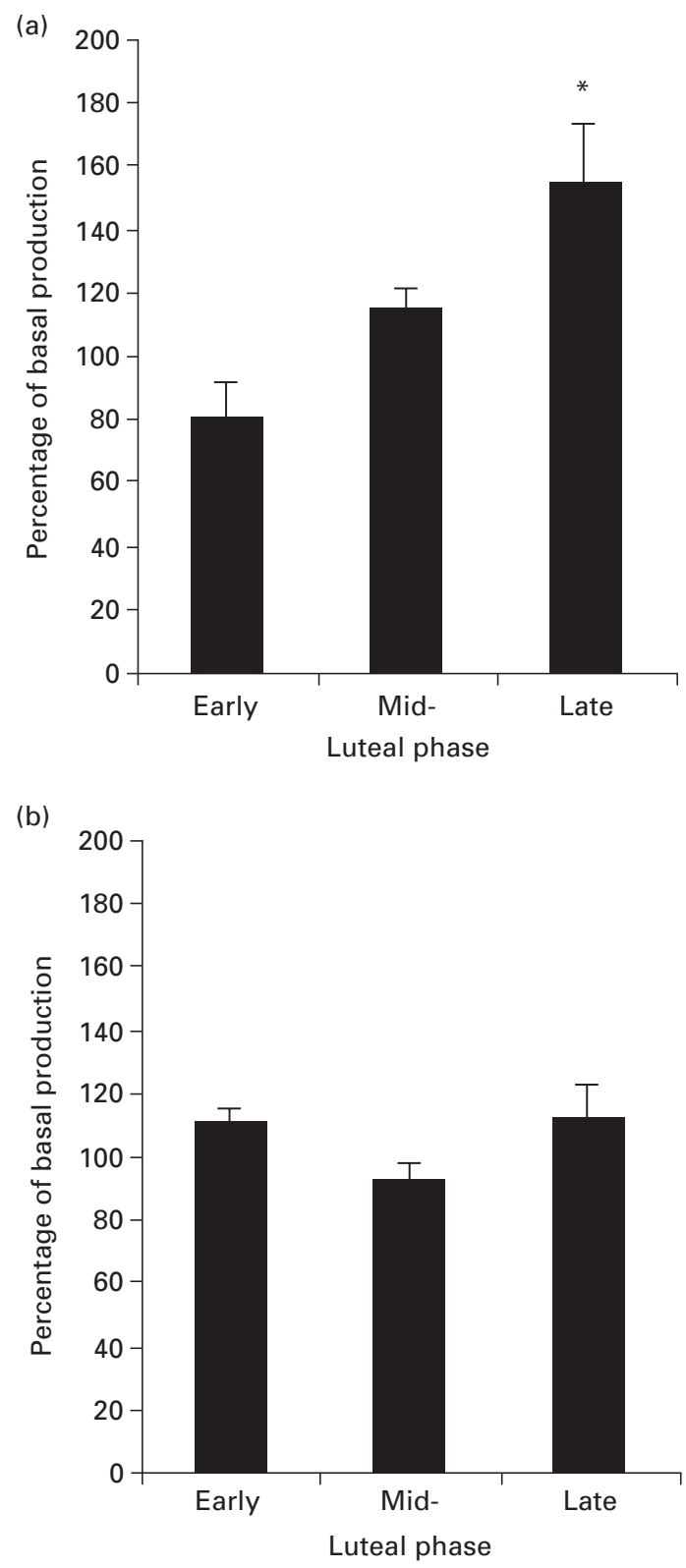

Fig. 4. Effect of nitric oxide on (a) insulin-like growth factor binding protein 1 (IGFBP-1) and (b) IGFBP-3 production by human corpus luteum of different ages. Tissue explants (three corpora lutea from the early luteal phase, $n=8$ slices; five corpora lutea from the mid-luteal phase, $n=12$ slices; and four corpora lutea from the late luteal phase, $n=10$ slices) were treated with LArginine $\left(1 \mathrm{mmol} \mathrm{I}^{-1}\right)$ for $4 \mathrm{~h}$. Results are expressed as percentages \pm SEM of basal values (Table 3 ). ${ }^{*} P<0.05$ versus corresponding basal value.

IGF receptor was not addressed directly in the present study, although the data indicate that the binding proteins and the receptor regulate the metabolic actions of IGFs in corpora lutea from the mid-luteal phase. IGF-I exerts a luteotrophic action by stimulating progesterone and oestradiol synthesis in cultures of luteal cells from the midluteal phase (Devoto et al., 1995; Niswender et al., 2000).
In this context, in the human corpus luteum, a potential direct effect of IGFBPs may operate independently from the effect of IGFs described in other systems (Ferry et al., 1999). However, a gradual increase in the number of positively stained cells and the intensity of immunostaining for IGF-I and IGFBP-1 was detected with increasing age of corpus luteum, in agreement with the amounts of IGF-I and IGFBP1 found in culture media. Collectively, these data indicate that IGF-I and IGFBP-1 play a role in the regulation of the lifespan of the human corpus luteum.

Maximum steroidogenic activity in the corpus luteum occurs during the mid-luteal phase, as evidenced by oestradiol and progesterone production and, thereafter, a gradual decline in steroid synthesis, representing the involution period or late luteal phase of the corpus luteum. The involution may be due, in part, to a progressive decrease in the mRNA that encodes steroidogenic enzymes, to a decrease in the activities of these enzymes, or to a decrease in the number of cells composing the corpus luteum. Previous studies indicate that programmed cell death mechanisms may be involved in corpus luteum involution (Vega et al., 2000). Apoptosis occurs in cells of different organisms in physiological and pathological conditions, and allows the maintainence of homeostasis of the relevant organ (Schwartzman and Cidlowsky, 1993). In the human corpus luteum, apoptosis increases with age and is enhanced by NO, which exhibits pro-apoptotic activity (Vega et al., 2000).

IGF-I exerts anti-apoptotic action in several tissues (Janiga et al., 2000; Morales et al., 2000; Remacle et al., 2000). One of the mechanisms by which IGF-I promotes cell survival in rat fibroblasts is via downregulation of the pro-apoptic protein Bad by activation of phosphatidylinositol 3-kinase and Akt, leading to the sequestration of phospho-Bad in the cytosol (Kulik and Weber, 1998). In PC12 cells, IGF-I mediates the expression of the antiapoptotic protein $\mathrm{Bcl}-\mathrm{x}_{\mathrm{L}}$, which plays a role in cell survival (Párrizas and LeRoith, 1997), and IGF-I also inhibits the downregulation of $\mathrm{Bcl}-2$ protein induced by hypoxia in cortical neurone cultures (Pugazhenthi et al., 1999a). The precise mechanism by which IGF-I sustains the expression of $b c l-2$ has not been elucidated. IGF-I apparently increases bcl-2 expression at transcription, because $b c /-2$ promoter is positively regulated by the nuclear transcription factor CREB, which can be activated by IGF-I (Pugazhenthi et al., 1999b). NO causes a decrease in Bcl-2 concentrations in corpora lutea from the mid- and late luteal phases (Vega et al., 2000) but does not induce changes in corpora lutea from the early luteal phase. In the present study, NO increased IGF-I concentration in early stage corpora lutea. It is not known whether these two issues are linked in the regulation of the lifespan of the human corpus luteum, although it is possible that, in the corpus luteum in the early luteal phase, the presence of IGF-I represents a protective mechanism that maintains $\mathrm{Bcl}-2$ expression in response to the action of pro-apoptotic agents such as NO.

The reduction in steroid production observed during 
luteal regression was coincident with the increase in IGFBP1 concentration in both basal and NO-treated corpora lutea. Moreover, the gradual increase in IGFBP-1 concentration in human corpora lutea during the luteal phase is in agreement with studies in bovine corpora lutea, in which IGFBP-1 expression increased during luteolysis (Sayre et al., 2000). Furthermore, hypoxia in HepG2 cells stimulated the expression of IGFBP-1 (Tazuke et al., 1998). NO increases IGFBP-1 concentration, particularly in corpora lutea from the late luteal phase, indicating that in the stress condition associated with corpora lutea from the late luteal phase (Vega et al., 1994), the concentration of IGFBP1 increases as a regulatory mechanism to restrict IGF-I bioavailability.

In summary, the present investigation revealed that the expression of growth factors and their binding proteins undergoes modification throughout the luteal phase and that NO regulates IGF and IGFBP protein concentrations. Collectively, these data indicate that growth factors may mediate NO action in the human corpus luteum and, therefore, the lifespan of the corpus luteum. Moreover, the increased expression of IGF-I and IGFBP-1 in the human corpus luteum from the late luteal phase, in addition to the effect of NO on IGFBP-1 concentration, indicate that these proteins are involved in human luteal regression, and are likely to be associated with a mechanism of programmed cell death.

The authors are grateful to Olga Castro (School of Medicine, University of Chile) for technical assistance; Bárbara Angel (post graduate student, School of Medicine, University of Chile) for helping with immunohistochemical studies; and the women who donated tissue. This work was supported by FONDECYT 1980899.

\section{References}

Angervo M, Koisteinen R, Suikkari AM and Seppala M (1991) Insulin-like growth factor binding protein 1 inhibits the DNA amplification induced by insulin-like growth factor I in human granulosa-luteal cells Human Reproduction 6 770-773

Castro A, Castro O, Troncoso JL, Kohen P, Simon C, Vega M and Devoto L (1998) Luteal leukocytes are modulators of the steroidogenic process of mid-luteal cells Human Reproduction 13 1584-1589

Davis JS, Way JV and Kell BA (1996) Mechanisms of hormone and growth factor action in the bovine corpus luteum Theriogenology $\mathbf{4 5}$ $1351-1380$

Devoto L and Vega M (1996) Regulación endocrita, paracrina y autocrina del cuerpo lúteo humano. In Reproducción Humana pp 51-63 Eds J Remohi, C Simon, A Pellicer and F Bonilla-Musoles. McGraw Hill Interamericana, Madrid

Devoto L, Kohen P, Castro M, Vega M, Troncoso JL and Charreau E (1995) Multihormonal regulation of progesterone synthesis in cultured human mid-luteal cells Journal of Clinical Endocrinology and Metabolism 80 1566-1570

Dews M, Prisco M, Peruzzi F, Romano G, Morrione A and Baserga R (2000) Domains of the insulin-like growth factor I receptor required for the activation of extracellular signal-regulated kinases Endocrinology 141 1289-1300

Dimmeler S and Zeiher AM (1997) Nitric oxide and apoptosis: another paradigm for the double-edge role of nitric oxide Nitric Oxide $\mathbf{1}$ 275-281

Einspanier R, Miyamoto A, Schams D, Muller M and Brem G (1990) Tissue concentration, mRNA expression and stimulation of IGF-I in luteal tissue during the oestrous cycle and pregnancy of cows Journal of Reproduction and Fertility $\mathbf{9 0} 439-445$

El-Roeiy A, Chen X, Roberts VJ, Shimasakai S, Ling N, LeRoith D, Roberts CT, Jr and Yen SS (1994) Expression of the genes encoding the insulinlike growth factors (IGF-I and II), the IGF and insulin receptors, and IGFbinding proteins 1-6 and the localization of their gene products in normal and polycystic ovary syndrome ovaries Journal of Clinical Endocrinology and Metabolism 78 1488-1496

Erickson GF, Garzo VG and Magoffin DA (1989) Insulin like growth factor I regulates aromatase activity in human granulosa and granulosa luteal cells Journal of Clinical Endocrinology and Metabolism 69 716-724

Feld S and Hirschberg R (1996) Growth hormone, the insulin-like growth factor system, and the kidney Endocrine Reviews 17 423-480

Ferry RJ, Jr, Cerri RW and Cohen P (1999) Insulin-like growth factor binding proteins: new proteins, new functions Hormone Research $\mathbf{5 1}$ 53-67

Fraser H, Lunn S, Kim H, Duncan WC, Rodger FE, Illingworth PJ and Erickson GF (2000) Changes in insulin-like growth factor-binding protein 3 messenger ribonucleic acid in endothelial cells of the human corpus luteum: a possible role in luteal development and rescue Journal of Clinical Endocrinology and Metabolism 85 1672-1677

Gadsby JE, Lovdal JA, Samaras S, Barber JS and Hammond JM (1996) Expression of the messenger ribonucleic acids for insulin-like growth factor I and insulin-like growth factor binding proteins in porcine corpora lutea Biology of Reproduction 54 339-346

Garcia H, Henriquez C, Ugarte F, Fernandez E, Beas F, Iniguez G, Boric F, Pizarro $\mathbf{F}$ and Cassorla $\mathbf{F}$ (1996) GH-IGF axis during catch up growth in small for gestanional age (SGA) infants Journal of Pediatric Endocrinology and Metabolism 9 561-567

Holst N, Kierulf KH, Seppala M, Koistinen R and Jacobsen MB (1997) Regulation of insulin-like growth factor-binding protein 1 and progesterone secretion from human granulosa-luteal cells: effects of octreotide and insulin Fertility and Sterility 68 478-482

Janiga TA, Rind HB and von Bartheld CS (2000) Differential effects of the trophic factors BDNF, NT-4, GDNF and IGF-I on the isthmo-optic nucleus in chick embryos Journal of Neurobiology 43 289-303

Johnson MC, Devoto L, Retamales Y, Kohen P, Troncoso JL and Aguilera G (1996) Localization of insulin-like growth factor (IGF-I) and IGF-I receptor expression in human corpora lutea: role in estradiol secretion Fertility and Sterility 65 489-494

Johnson MC, Diaz A, Stocco C, Palomino A, Devoto L and Vega M (1999) Antisteroidogenic action of nitric oxide on human corpus luteum in vitro. Endocrine 11 31-36

Kirby CJ, Thatcher WW, Collier RJ and Lucy MC (1996) Effects of growth hormone and pregnancy on expression of growth hormone receptor, insulin-like growth factor I, and insulin-like growth factor binding protein 2 and 3 genes in bovine uterus, ovary and oviduct Biology of Reproduction 55 996-1002

Kulik G and Weber MJ (1998) Akt-dependent and -independent survival signaling pathways utilized by insulin-like growth factor I Molecular and Cellular Biology 18 6711-6718

Lessey BA, Damjanovich L, Coutifaris C, Castelbaum A, Albelda SM and Buck CA (1992) Integrin adhesion molecules in the human endometrium. Correlation with the normal and abnormal menstrual cycle Journal of Clinical Investigation 90 188-195

Morales MP, Galvez A, Eltit JM, Ocaranza P, Diaz Araya G and Lavandero S (2000) IGF-I regulates apoptosis of cardiac myocyte induced by osmotic stress Biochemical and Biophysical Research Communications 270 1029-1035

Niswender GD, Juengel JL, Silva PJ, Rolyson MK and McIntush EW (2000) Mechanisms controlling the function and lifespan of the corpus luteum Physiological Reviews 80 1-29

Norman J and Cameron I (1996) Nitric oxide in the human uterus Reviews of Reproduction 1 61-68

Noyes RW, Hertig AT and Rock J (1950) Dating the endometrial biopsy Fertility and Sterility 1 3-12

Parmer TG, Roberts CT, Jr, LeRoith D, Adashi EY, Khan Y, Solan N, Nelson S, Zilberstein M and Gibori G (1991) Expression, action and steroidal 
regulation of insulin-like growth factor I (IGF-I) and IGF-I receptor in the rat corpus luteum: their differential role in the two cell populations forming the corpus luteum Endocrinology 129 2924-2932

Párrizas M and LeRoith D (1997) Insulin-like growth factor I inhibition of apoptosis is associated with increased expression of the $b c l-x L$ gene product Endocrinology 138 1355-1358

Perks CM, Denning-Kendall PA, Gilmour RS and Wathes DC (1995) Localization of messenger ribonucleic acids for insulin-like growth factor I (IGF-I), IGF-II, and the type 1 IGF receptor in the ovine ovary throughout the estrous cycle Endocrinology 136 5266-5273

Pugazhenthi S, Boras T, O'Connor D, Meintzer MK, Heidenreich KA and Breusch JE (1999a) Insulin-like growth factor I-mediated activation of the transcription factor camp response element-binding protein in PC12 cells: involvement of p38 mitogen-activated protein kinase-mediated pathway Journal of Biological Chemistry 274 2829-2837

Pugazhenthi S, Miller E, Sable C, Young P, Heidenreich KA, Boxer LM and Reusch JE (1999b) Insulin-like growth factor I induces bcl-2 promoter through the transcription factor c-AMP-response element-binding protein Journal of Biological Chemistry 27427 529-27 535

Remacle Bonnet MM, Garouste FL, Heller S, Andre F, Marvaldi JL and Pommier GJ (2000) Insulin-like growth factor I protects colon cancer cells from death factor-induced apoptosis by potentiating necrosis factor alpha-induced mitogen-activated protein kinase and nuclear factor kappa B signaling pathway Cancer Research 60 2007-2017

Sauerwein H, Miyanato A, Gunther J, Meyer HH and Schams D (1992) Binding and action of insulin-like growth factors and insulin in bovine luteal tissue during the oestrous cycle Journal of Reproduction and Fertility 96 103-115

Sayre BL, Taft R, Inskeep EK and Killefer J (2000) Increased expression of insulin-like growth factor binding protein 1 during induced regression of bovine corpora lutea Biology of Reproduction $6321-29$
Schwartzman R and Cidlowsky J (1993) Apoptosis: the biochemistry and molecular biology of programmed cell death Endocrine Reviews $\mathbf{1 5}$ 133-151

Talavera F and Menon KMJ (1991) Studies on rat luteal cell response to insulin-like growth factor I (IGF-I): identification of a specific cell membrane receptor for IGF-I in the luteinized rat ovary Endocrinology 129 1340-1346

Tazuke SI, Mazure NM, Sugawara J et al. (1998) Hypoxia stimulates insulin-like growth factor binding protein 1 (IGFBP-1) gene expression in HepG2 cells: a possible model for IGFBP-1 expression in fetal hypoxia Proceedings of the National Academy of Sciences USA 9510 188-10 193

Van Obberghen-Schilling E and Pouyssegur J (1983) Mitogen potentiation action and binding of insulin-like growth factors in Chinese hamster fibroblast Experimental Cell Biology 151 207-214

Vega M, Castillo T, Retamales I, Las Heras J, Devoto L and Videla LA (1994) Steroidogenic capacity and oxidative stress-related parameters in human luteal cell regression Free Radical Biology and Medicine 17 493-499

Vega M, Johnson MC, Díaz HA, Urrutia L, Troncoso JL and Devoto L (1998) Regulation of human luteal steroidogenesis in vitro by nitric oxide Endocrine 8 185-191

Vega M, Urrutia L, Iniguez G, Gabler F, Devoto L and Johnson MC (2000) Nitric oxide induces apoptosis in the human corpus luteum in vitro. Molecular Human Reproduction 6 681-687

Received 25 April 2001.

First decision 30 May 2001.

Final revision received 4 September 2001.

Accepted 7 September 2001. 